\title{
New Insights on the Mechanism(s) of the Dominant Negative Effect of Mutant Thyroid Hormone Receptor in Generalized Resistance to Thyroid Hormone
}

Paul M. Yen, Akira Sugawara, Samuel Refetoff, ` and William W. Chin

Division of Genetics, Department of Medicine, Brigham and Women's Hospital, Howard Hughes Medical Institute and Harvard Medical School, Boston, Massachusetts 02115; and *Departments of Medicine and Pediatrics and The J. P. Kennedy,

Jr. Mental Retardation Research Center, The University of Chicago, Chicago, Illinois 60637

\begin{abstract}
Generalized resistance to thyroid hormone (GRTH) is a syndrome of hyposensitivity to triiodothyronine $\left(T_{3}\right)$ that displays autosomal dominant inheritance. The genetic defect commonly lies in the ligand-binding domain of one of the TR $\beta$ alleles. Since there are two major thyroid hormone receptor (TR) isoforms, TR $\alpha$ and TR $\beta$, it is not known how the mutant receptor mediates a dominant negative effect. Previously, we showed that $T_{3}$ caused dissociation of TR homodimers and TR $\alpha / T R \beta$ dimers from several thyroid hormone response elements (TREs). Hence, we used the electrophoretic mobility shift assay to compare the effect of $T_{3}$ on the DNA binding of mutant TR $\beta-1$ (Mf-1) from a kindred with GRTH with normal TR $\beta$. Mf-1 bound better as a homodimer than TR $\beta$, but dissociated from DNA only at high $T_{3}$ concentrations. Both receptors heterodimerized with nuclear auxiliary proteins. They also dimerized with $T R \alpha$ and with each other. Surprisingly, $T_{3}$ disrupted the DNA binding of the Mf-1 / TR isoform dimers. Thus, mechanisms for the dominant negative effect by mutant TRs likely involve either increased binding to TREs by mutant homodimers that cannot bind $T_{3}$ (hence cannot dissociate from DNA) and/or the formation of inactive mutant TR/nuclear protein heterodimers. (J. Clin. Invest. 1992. 90:1825-1831.) Key words: thyroid hormone receptor $\bullet$ thyroid hormone resistance $\cdot$ homodimer $\bullet$ heterodimer $\cdot$ DNA binding
\end{abstract}

\section{Introduction}

Generalized resistance to thyroid hormone (GRTH) ${ }^{1}$ is a syndrome characterized by elevated circulating levels of thyroxine $\left(\mathrm{T}_{4}\right)$ and triiodothyronine $\left(\mathrm{T}_{3}\right)$ with inappropriately normal or increased levels of thyroid-stimulating hormone $(1,2) . \mathrm{Pa}-$

Address correspondence to Dr. Paul M. Yen, G. W. Thorn Research Building, Room 905, Brigham and Women's Hospital, 20 Shattuck Street, Boston, MA 02115.

Received for publication 14 February 1992 and in revised form 12 May 1992.

1. Abbreviations used in this paper: $\mathrm{EC}_{50}, 50 \%$ effective concentration; EMSA, electrophoretic mobility shift assay; GRTH, generalized resistance to thyroid hormone; $R X R$, retinoid $X$ receptor; TR, thyroid hormone receptor; TRAP, thyroid hormone receptor auxiliary protein; TRE, thyroid hormone response element.

J. Clin. Invest.

(c) The American Society for Clinical Investigation, Inc.

$0021-9738 / 92 / 11 / 1825 / 07 \$ 2.00$

Volume 90, November 1992, 1825-1831 tients with this syndrome have partial refractoriness to the effects of thyroid hormone, which is variable in individual target tissues. Furthermore, the clinical phenotypes are different among affected families $(2,3)$. The pattern of inheritance of GRTH is autosomal dominant in the majority of cases $(2,3)$, although the occurrence of autosomal recessive transmission has been documented in one family (4).

Although thyroid hormone receptor (TR) mutations had been suspected based on decreased thyroid hormone binding in fibroblasts of affected patients $(3,5)$, direct demonstration of TR mutations could not be undertaken until cDNAs encoding TRs had been identified. Recently, two different thyroid hormone receptor genes, hTR $\alpha$ and hTR $\beta$, that encode highly homologous DNA-binding proteins that bind $\mathrm{T}_{3}$ have been identified in humans (6-8). The TRs are members of a large superfamily of receptors, including the estrogen, glucocorticoid, vitamin $D$, and retinoic acid receptors $(9,10)$. In common with other members, they have several domains, including a central DNA-binding domain containing two "zinc fingers" and a carboxyl-terminal ligand-binding domain.

Recent studies of subjects with GRTH have identified single amino acid substitutions in the ligand-binding domain of their TR $\beta$-1 (11-15). In the first two families described, the mutant TR $\beta$-1 had either glycine 345 replaced by arginine (Mf1) or proline 453 replaced by histidine $(11,12)$. Mutations in all families with GRTH so far characterized cluster near those described in these two families $(15,16)$. Affected members of these families have one normal and one abnormal $\operatorname{TR} \beta$ allele, consistent with the autosomal dominant mode of inheritance predicted by pedigree analysis. In vitro transcription and translation of the mutant receptors in some of the families showed either reduced or virtually absent $T_{3}$-binding affinity $(13,16$, 17). Transient transfection assays using two of the TR $\beta$-1 point mutants (including Mf- 1 ) have shown that they not only fail to mediate normal $\mathrm{T}_{3}$-regulated transcription but also can block the $T_{3}$-regulated transcription by normal TRs $(18,19)$. The mechanism of this dominant negative effect of the mutant $\operatorname{TR} \beta-1$ allele on the normal $\operatorname{TR} \beta$ and $\operatorname{TR} \alpha-1$ isoforms is open to speculation. It has been hypothesized that the mutant $\operatorname{TR} \beta-1$ can dimerize with normal TRs interfering with their ability to mediate ligand-regulated transcription (18-20). Indeed, it has been recently shown that $\operatorname{TR} \beta$ can homodimerize (21-25) and dimerize with other TR isoforms (25) on DNA sequences containing thyroid hormone response elements (TREs) from thyroid hormone-regulated genes.

Several observations have complicated the elucidation of the molecular mechanism for thyroid hormone resistance. First, a nuclear protein(s), designated thyroid hormone receptor auxiliary protein (TRAP), has been shown to heterodimerize with TRs and enhance their binding to TREs $(21,26-29)$. 
Second, addition of $\mathrm{T}_{3}$ can cause dissociation of TR $\alpha-1$ and $\mathrm{TR} \beta-1$ homodimers, as well as TR $\alpha-1 / \mathrm{TR} \beta$ - 1 dimers from certain TREs (25). In contrast, TR/TRAP heterodimers remain bound to these TREs in the presence of $T_{3}$, suggesting that the heterodimer, not the homodimer, may be the functionally relevant receptor complex in ligand-mediated transcription. Lastly, Hamada et al. (30) recently cloned a protein, $\mathrm{H}-2 \mathrm{RIIBP}$, that bound to a MHC class I gene regulatory element and vitellogenin gene $\mathrm{A} 2$ estrogen response element. This protein has high sequence homology with retinoid $\mathrm{X}$ receptor $\alpha$ $(\operatorname{RXR} \alpha)$ and is now designated $\operatorname{RXR} \beta(31)$. These proteins also bind to the $\beta$-retinoic acid receptor gene regulatory element $(31,32)$. Additionally, they heterodimerize with TRs, resulting in enhanced TR binding to TREs and increased levels of $\mathrm{T}_{3}$-mediated transcription (31-35). RXRs are members of the same superfamily of receptors as TRs and bind to a putative endogenous ligand, 9-cis retinoic acid (36). Recently, $T_{3}$ has been shown to have no effect on TR/RXR heterodimer binding to TREs (36a).

To better understand the mechanism whereby mutant TRs of patients with GRTH exert a dominant negative effect, we compared the in vitro DNA-binding of a mutant TR $\beta$ (Mf-1) from kindred $M f$ with native human $T R \beta$-1. In particular, we examined homodimerization, receptor isoform dimerization, and receptor heterodimerization with TRAP and $R X R \beta$, using the electrophoretic mobility shift assay (EMSA). Additionally, we examined the effect of $T_{3}$ on the binding of these complexes. On the basis of our results, we propose that the mutant TR does not exert its dominant negative effect by direct dimerization with native $\operatorname{TR} \alpha-1$ or $\operatorname{TR} \beta-1$ from the normal allele, since $T_{3}$ induces a normal dissociation of these complexes from DNA. Instead, the occupation of TREs by mutant homodimers that cannot bind $T_{3}$ (hence cannot dissociate from DNA) and/or the formation of inactive mutant/TRAP complexes may be the mechanism(s) by which these mutant receptors mediate resistance to thyroid hormone.

\section{Methods}

Preparation of in vitro translated receptors. Previously described cDNA clones of rat TR $\alpha-1$ (TR $\alpha-1)$, human TR $\beta-1$ (TR $\beta-1)$, Mf-1, and $\Delta \mathrm{N}$ in pGEM (kindly provided by Dr. D. S. Darling, Brigham and Women's Hospital, Boston, MA), and mouse RXR $\beta$ ( or H-2RIIBP) in pBS (kindly provided by Dr. K. Ozato, National Cancer Institute, Bethesda, MD) were used in these experiments $(6,28,30,37,38)$. Each cDNA was linearized with the appropriate restriction endonuclease and used as a template for RNA synthesis with $T_{7}$ RNA polymerase. Unlabeled and $\left[{ }^{35} \mathrm{~S}\right]$ methionine-labeled receptors then were produced from rabbit reticulocyte lysates according to the manufacturer's instructions (Bethesda Research Laboratories, Bethesda, MD). Unprogrammed reticulocyte lysate was also incubated under the same conditions. The amount of translated protein was quantitated by TCA precipitation $(26,39)$ and by SDS-PAGE analysis of $\left[{ }^{35}\right.$ S $]$ methioninelabeled receptors that showed labeled proteins of expected molecular weights.

Preparation of nuclear extracts. Nuclear extract from the rat pituitary lactotropic cell line 235-1 was prepared and stored as previously described (26). These cells do not bind $\mathrm{T}_{3}$, and so presumably do not have endogenous TRs. Extracts then were dialyzed against $20 \mathrm{mM}$ Hepes ( $\mathrm{pH}$ 7.3), $5 \mathrm{mM}$ 2-mercaptoethanol, $50 \mathrm{mM} \mathrm{NaCl}, 2 \mathrm{mM}$ EGTA, $10 \%$ glycerol, and $0.1 \mathrm{mM}$ phenylmethylsulfonylfluoride and were centrifuged $10,000 \mathrm{~g}$ for $15 \mathrm{~min}$. Aliquots were stored frozen at $-70^{\circ} \mathrm{C}$ until used in DNA-binding assays.
Design and preparation of labeled DNA probes. Double-stranded oligonucleotides containing TREs from either the chicken lysozyme gene (F2) -2344 to $-2326(40)$ or direct repeats of two half sites (AGGTCA) separated by a gap of four nucleotides (DR4) (41) in the context of the $F 2$ flanking sequences were used in our experiments. The oligonucleotides were end-labeled with $\left[{ }^{32} \mathrm{P}\right] \gamma$-ATP by T4 polynucleotide kinase. The labeled probes were then purified on a $9 \%$ polyacrylamide gel under nondenaturing conditions. The full-length probe was cut from the gel and extracted in $400 \mu \mathrm{l} 0.5 \mathrm{M}$ ammonium acetate and $1 \mathrm{mM}$ EDTA at $37^{\circ} \mathrm{C}$ for $4 \mathrm{~h}$. After microcentrifugation, labeled probe was extracted from the supernatant by ethanol precipitation. The pellet was washed with $70 \%$ ethanol, resuspended in TE buffer ( $10 \mathrm{mM}$ Tris, $1 \mathrm{mM}$ EDTA [ $\mathrm{pH} 8.0]$ ), and stored at $-20^{\circ} \mathrm{C}$ until used in DNA-binding assays.

DNA-binding assay/EMSA. Unlabeled receptor preparations or unprogrammed reticulocyte lysate $(0.5-6.0 \mu \mathrm{l})$ and $10,000 \mathrm{cpm}$ oligonucleotide probe were incubated in $20 \mu \mathrm{l}$ of $25 \mathrm{mM}$ Hepes ( $\mathrm{pH} 7.5$ ), 5 $\mathrm{mM} \mathrm{MgCl}$, 4 mM EDTA, $2 \mathrm{mM}$ dithiotreitol, $110 \mathrm{mM} \mathrm{NaCl}, 5 \mu \mathrm{g} / \mathrm{ml}$ bovine serum albumin, and $0.8 \mu \mathrm{g}$ sheared salmon sperm DNA (Sigma Chemical Co., St. Louis MO) for $30 \mathrm{~min}$ at room temperature. Different concentrations of 3,5,3' L-triiodothyronine $\left(T_{3}\right)$ (Sigma Chemical Co.) were also added to the samples in certain experiments. To study TR/TRAP heterodimerization, $1.0 \mu \mathrm{g}$ nuclear extract was added to each sample. To study receptor isoform dimerization or heterodimerization with $\operatorname{RXR} \beta$, we preincubated samples at $30^{\circ} \mathrm{C}$ for $10 \mathrm{~min}$ before adding oligonucleotide probe. After incubation, samples were then subjected to electrophoresis on $4 \%$ polyacrylamide gels in $0.5 \times \mathrm{TBE}$ buffer (45 mM Tris-borate, and $1 \mathrm{mM}$ EDTA) for $75 \mathrm{~min}$ at $4^{\circ} \mathrm{C}$. Proteins on the gel were fixed by incubation in $7 \%$ acetic acid and $10 \%$ isopropanol for $15 \mathrm{~min}$ at room temperature. The gels were dried under vacuum at $80^{\circ} \mathrm{C}$ for $1 \mathrm{~h}$ and autoradiographed with an intensifying screen. Film exposure to the gels ranged from 12 to $48 \mathrm{~h}$.

\section{Results}

We first examined the binding of native human TR $\beta-1$ and Mf-1 to a labeled oligonucleotide containing the chick lysozyme gene TRE (F2) by using EMSA. As previously shown with TR $\beta$-1 (25), Mf-1 bound almost exclusively as a homodimer on this TRE (Fig. $1 A$ ). Interestingly, Mf-1 bound better than TR $\beta-1$ to this TRE since the same amount of in vitrotranslated receptor (as quantitated by TCA precipitation and SDS-PAGE analyses of ${ }^{35} \mathrm{~S}$-labeled receptor) was added to each DNA-binding reaction. Additionally, the bound Mf- 1 homodimer band moved with a slower mobility than the TR $\beta-1$ homodimer band (Fig. $1 A$ ). A similar difference in mobility was seen in the faint monomer bands for these receptors on longer exposures of the gel (data not shown). Scatchard analyses of homodimer binding to F2 (Fig. 2) showed that both receptor homodimers had a similar affinity for F2 (TR $\beta-1 K_{d}=0.78$ $\mathrm{nM}$, Mf-1 $K_{\mathrm{d}}=1.2 \mathrm{nM}$ ); however, total Mf-1 homodimer bound to $F 2$ was threefold greater than $\operatorname{TR} \beta$-1 for the same amount of in vitro-translated receptor added to the DNAbinding reaction (TR $\beta-1$ homodimer bound $\left[N_{\max }\right]=0.775$ $\mathrm{fm} /$ reaction, Mf- 1 homodimer bound $\left[\mathrm{N}_{\max }\right]=2.46 \mathrm{fm} / \mathrm{reac}-$ tion). When $T_{3}$ was added to the DNA-binding reactions, TR $\beta$ - 1 homodimer binding decreased with an $50 \%$ effective concentration $\left(\mathrm{EC}_{50}\right)$ of $\sim 1.0 \times 10^{-9} \mathrm{M}$, (Fig. $1 A$ ), as reported previously (25). In contrast, $\mathrm{T}_{3}$ did not decrease Mf-1 homodimer binding to $\mathrm{F} 2$ unless much higher concentrations of $\mathrm{T}_{3}$ were added $\left(\mathrm{EC}_{50}\right.$ of $\sim 1.0 \times 10^{-6} \mathrm{M}$ ) (Fig. $1 A$ and $B$ ). This diminished $\mathrm{T}_{3}$ effect on Mf- 1 DNA-binding is consistent with the minimal $\mathrm{T}_{3}$ binding previously reported for in vitrotranslated Mf-1 $(18,19)$. 

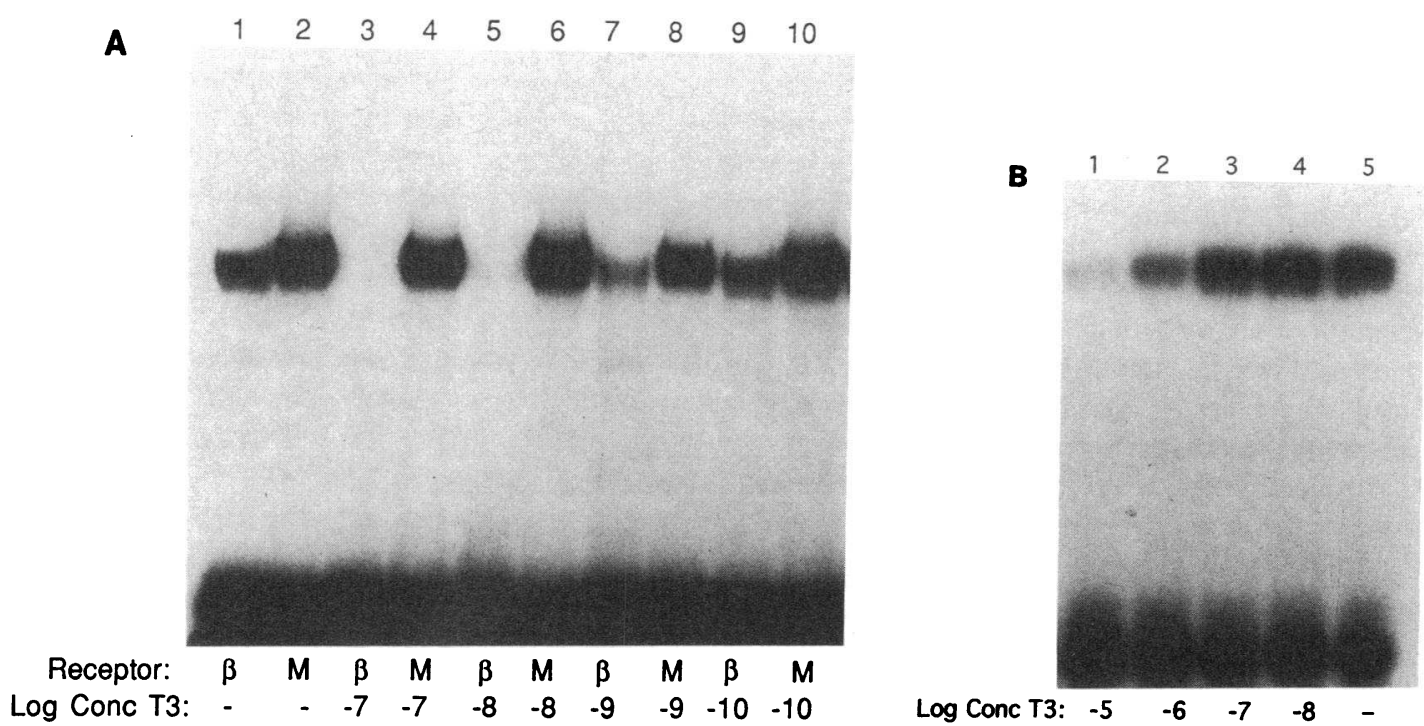

Figure 1. T3 effect on TR $\beta-1$ and Mf-1 homodimer binding to F2. Equal concentrations of in vitro translated TR $\beta-1$ and Mf-1 and labeled F2 probe were used in the absence or presence of varying concentrations of T3 for analysis by EMSA as described in Methods. Lanes are numbered $1-10$ on top of the figure and the additives are indicated at the bottom. $\beta$, wild-type TR $\beta-1$; M, the mutant TR $\beta$ (Mf-1).

We next examined whether Mf-1 could form heterodimers with TRAP on two different TREs, F2 and DR4 (a synthetic, positively regulated TRE in which half-sites are oriented as direct repeats and separated by a gap of four nucleotides) (41). Both TR $\beta-1$ and Mf- 1 formed heterodimers with TRAP on these TREs when incubated with pituitary nuclear extract (Fig. 3 , lanes 4, 6, 10, and 12). However, the Mf-1/TRAP heterodimer band migrated slightly slower than the TR $\beta-1 /$ TRAP

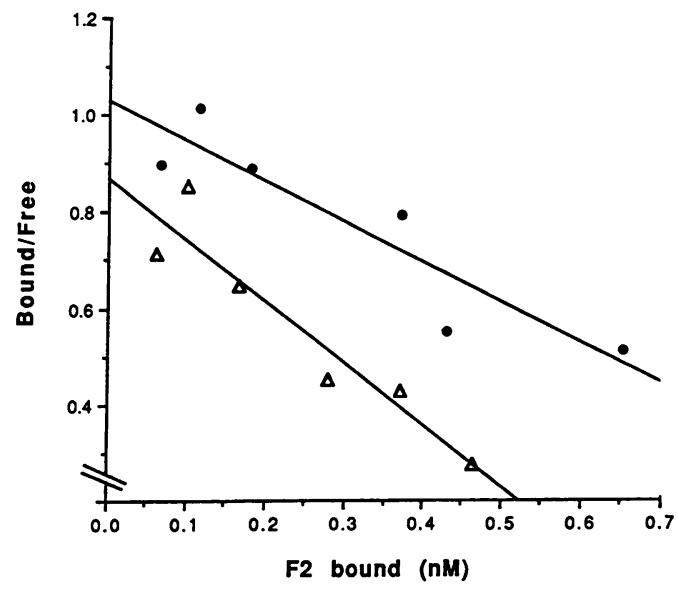

Figure 2. Scatchard analysis of TR $\beta-1$ and Mf-1 homodimer binding to F2. Increasing amounts of labeled F2 probe $(1,250-40,000$ $\mathrm{cpm} /$ reaction) were incubated with TR $\beta-1$ and Mf-1 and then were analyzed by EMSA. The radioactivity in bands containing bound homodimer and free probe were quantitated by counting the corresponding gel sections. Each point represents the mean of duplicate determinations. ( $\operatorname{TR} \beta-1(\Delta): K_{\mathrm{d}}=0.78 \mathrm{nM}, \mathrm{N}_{\max }=1.39 \mathrm{fm} /$ reaction, $r=0.90 ; \mathrm{Mf}-1(\bullet): K_{\mathrm{d}}=1.20 \mathrm{nM}, \mathrm{N}_{\max }=2.46 \mathrm{fm} /$ reaction, $r$ $=0.84$ ). Note that 1.75 -fold more TR $\beta$-1 was added so that the amount bound to $F 2$ in the absence of $T 3$ would be equivalent to that of Mf-1. TR $\beta-1 \mathrm{~N}_{\max }$ normalized for the amount of added receptor $=0.775 \mathrm{fm} /$ reaction. Multiple linear regression analyses of the slopes showed no significant difference between the two $K_{d} s(P=0.16)$. Similar results were obtained in a second experiment. heterodimer band. Additionally, the pattern of heterodimer and homodimer binding to the TREs was different for TR $\beta$-1 and Mf- 1 . TR $\beta-1$ formed heterodimers preferentially over homodimers on these TREs. As previously reported, when $T_{3}$ was added to TR $\beta-1$ and nuclear extract, homodimer no longer bound to DNA but heterodimer remained bound to F2. In contrast, both Mf- 1 and Mf- 1 /TRAP heterodimer remained bound to $\mathrm{F} 2$ in the presence of $10^{-7} \mathrm{M} \mathrm{T}_{3}$ (data not shown). We also examined whether these receptors could form heterodimers with $\operatorname{RXR} \beta$, a member of the steroid hormone receptor/TR superfamily that binds to the MHC Class I gene regulatory region and $\beta$-retinoic acid receptor gene $(28,29,35)$. Both

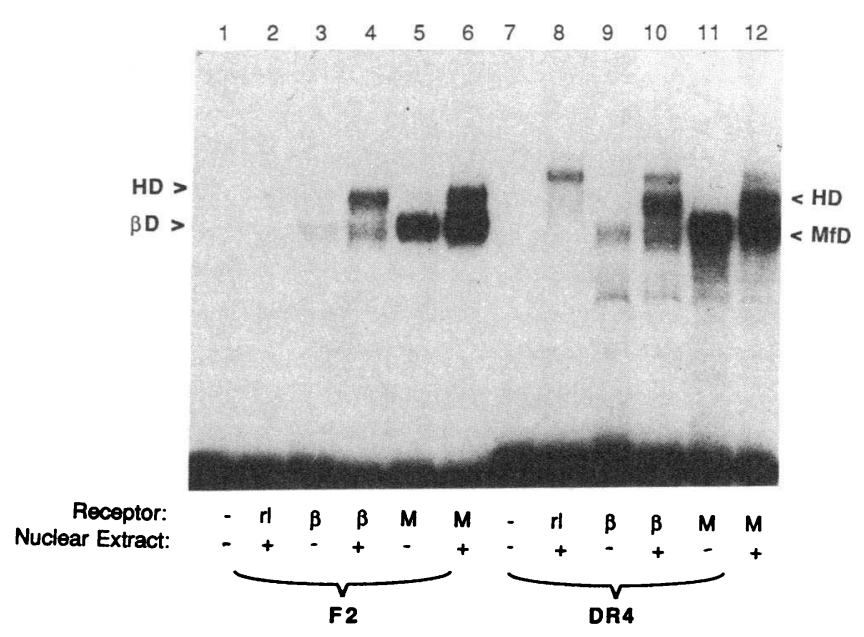

Figure 3. Comparison of $\mathrm{TR} \beta-1$ and $\mathrm{Mf}-1$ homodimers and receptor/TRAP heterodimer binding to two TREs (F2 and DR4). Equal amounts of TR $\beta-1$ and Mf- 1 were incubated with $1 \mu \mathrm{g}$ of nuclear extract from pituitary 235-1 cells and either F2 or DR4 probe and were analyzed by EMSA. Lanes are numbered 1-12 and the presence $(+)$ or absence $(-)$ of additives are indicated. $r l$, reticulocyte lysate; $\beta$, TR $\beta-1 ; \mathrm{M}, \mathrm{Mf}-1$; HD, receptor/TRAP heterodimer; $\beta \mathrm{D}$, TR $\beta-1$ homodimer; and $\mathrm{M} \mathrm{fD}$, Mf-1 homodimer. 
TR $\beta$ - 1 and Mf- 1 formed receptor/RXR $\beta$ heterodimers on F2 and DR4 (Fig. 4, lanes 3, 6, and 9) that were stable after $T_{3}$ addition (data not shown). Also, the receptor/TRAP heterodimer band migrated more slowly than the receptor/RXR $\beta$ heterodimer band, suggesting that TRAP in the pituitary may be different than $R X R \beta$ (Fig. 4, lanes 3, 4, 6, 7, 9, and 10).

To examine whether the mutant receptor could exert its dominant negative effect via direct interaction with other TR isoforms, we compared the formation of $\operatorname{TR} \alpha-1$ /TR $\beta-1$ dimers with TR $\alpha-1$ / Mf-1 dimers and the effect of $\mathrm{T}_{3}$ on DNA-binding by these dimers. We previously showed that incubating $\operatorname{TR} \alpha-1$ and $\operatorname{TR} \beta-1$ together produced $\operatorname{TR} \alpha-1 / \operatorname{TR} \beta-1$ dimers bound to $F 2$ and addition of $T_{3}$ decreased DNA-binding of these dimers (25). When TR $\alpha-1$ and Mf-1 were incubated together, there was loss of TR $\alpha-1$ homodimer band and formation of a new large band composed of mostly TR $\alpha-1 / \mathrm{Mf}-1$ dimers (faster migrating) and a small amount of residual Mf- 1 homodimers (slower migrating) (Fig. 5, lane 7). The presence of TR $\alpha-1 /$ Mf- 1 dimers was confirmed by coincubation with anti-TR $\alpha$ and $\operatorname{TR} \beta-1$ isoform-specific antibodies (42) in the DNA-binding reaction and observation of appropriate supershifts (data not shown). When $10^{-7} \mathrm{M} \mathrm{T}_{3}$ was added to the DNA-binding reactions, $\mathrm{T}_{3}$ abolished TR $\alpha-1 / \mathrm{Mf}-1$ dimer but not Mf- 1 homodimer binding to F2 (Fig. 5, lane 9). Only when $10^{-6} \mathrm{M} \mathrm{T}_{3}$ was added did Mf-1 homodimer dissociate from F2 (Fig. 5, lane 8 ). These data demonstrate that TR $\alpha-1 /$ Mf- 1 dimer behaves similarly to $\operatorname{TR} \alpha-1 / \operatorname{TR} \beta-1$ dimer, as it is more sensitive to the $T_{3}$-mediated decrease in homodimer binding to $F 2$ than the Mf- 1 homodimer. Moreover, these data suggest that $T_{3}$ only needs to bind to TR $\alpha-1$ for the $T R \alpha-1 / M f-1$ dimer to dissociate from $\mathrm{F} 2$ since $\mathrm{Mf}-1$ most likely does not bind $\mathrm{T}_{3}$ at $10^{-7} \mathrm{M}(18,19)$ and therefore does not affect Mf- 1 homodimer binding to DNA at this concentration (Fig. 1).

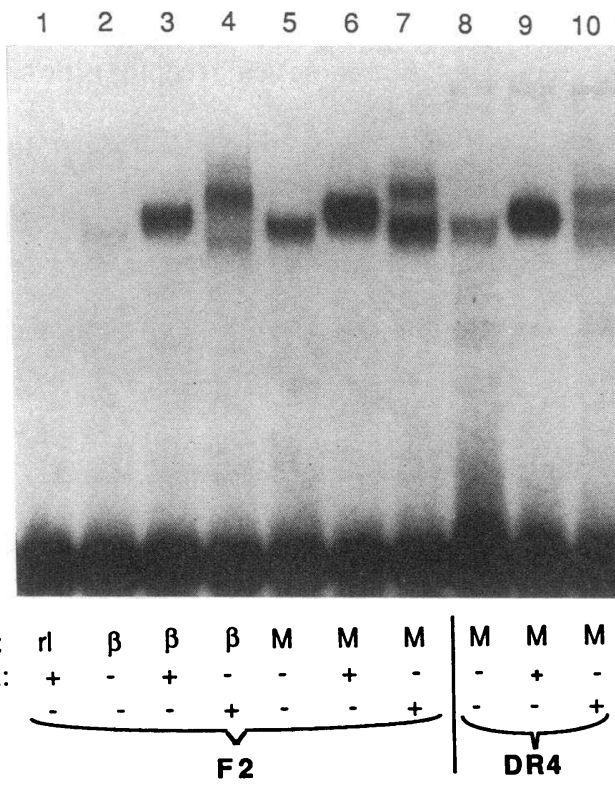

Figure 4. Comparison of TR $\beta$-1 and Mf-1 heterodimerization with TRAP and RXR $\beta$ on two TREs. Equal amounts of TR $\beta-1$ and $\mathrm{Mf}-1$ were incubated with $5 \mu \mathrm{l}$ in vitro-translated $\operatorname{RXR} \beta$ or $1 \mu \mathrm{g}$ of nuclear extract from pituitary 235-1 cells, then reacted with F2 or DR4, and analyzed by EMSA. For abbreviations, see legend to Fig. 3 . Note the faster mobility of RXR $\beta$ / TR than TRAP/TR heterodimers. TREbound Mf- 1 heterodimers predominated in the presence of TRAP but not $\operatorname{RXR} \beta$.

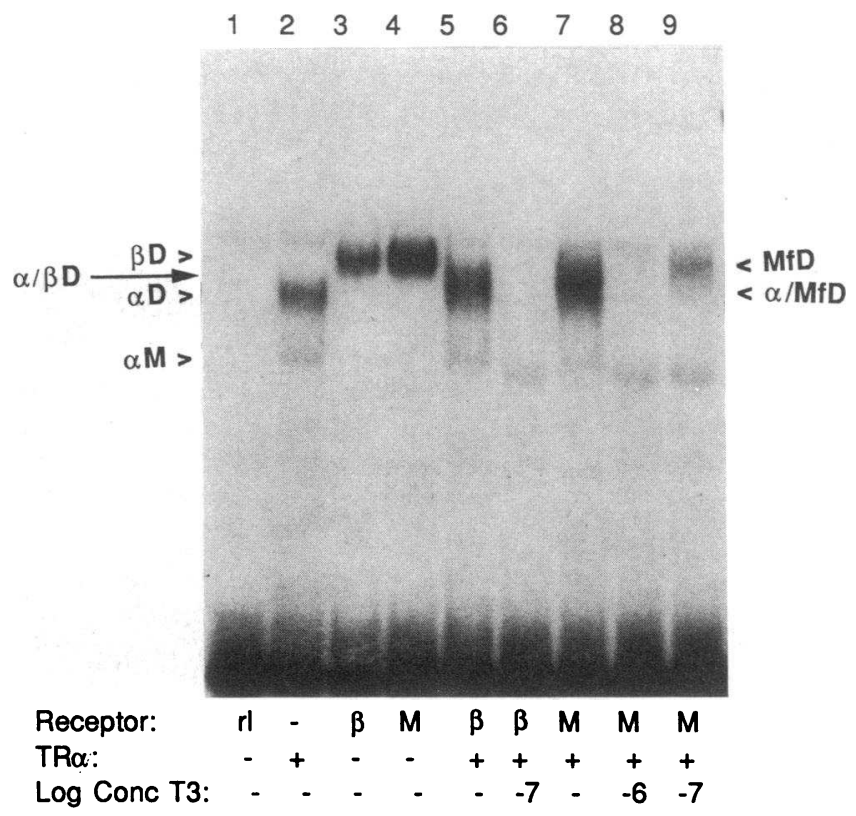

Figure 5. Formation of TR $\beta-1$ and Mf- 1 dimers with $\mathrm{TR} \alpha$ on $\mathrm{F} 2$ and the effect of T3. TR $\beta-1$ or Mf- $1(0.5 \mu \mathrm{l})$ was incubated with TR $\alpha(6$ $\mu \mathrm{l})$ in the presence and absence of T3 and was analyzed by EMSA. Note that in order to form similar amounts of bound TR to F2, 1.75-fold more TR $\beta$-1 than Mf- 1 was added to the DNA-binding reactions. Samples were analyzed on a 5\% polyacrylamide gel and run for $90 \mathrm{~min}$ at $4^{\circ} \mathrm{C}$ to enhance separation of the different receptor bands. The presence $(+)$ or absence $(-)$ of additives is indicated. $\mathrm{rl}$, reticulocyte lysate; $\beta$, TR $\beta-1 ; \mathrm{M}, \mathrm{Mf}-1 ; \alpha \mathrm{M}$, TR $\alpha$ monomer: $\alpha \mathrm{D}$, $\mathrm{TR} \alpha$ homodimer, $\beta \mathrm{D}, \mathrm{TR} \beta-1$ homodimer, $\mathrm{MfD}, \mathrm{Mf}-1$ homodimer, $\alpha / \beta \mathrm{D}, \mathrm{TR} \alpha / \mathrm{TR} \beta$-1 dimer; $\alpha / \mathrm{Mf}-1, \mathrm{TR} \alpha / \mathrm{Mf}-1$ dimer.

We next compared the formation of $\operatorname{TR} \beta-1$ homodimer with Mf-1 / TR $\beta$-1 dimer since direct interaction of the mutant receptor with wild-type $\operatorname{TR} \beta-1$ receptor could account for its dominant negative effect. To demonstrate $\mathrm{Mf}-1 / \mathrm{TR} \beta-1$ dimer binding we used a mutant rat $\operatorname{TR} \beta-1, \Delta \mathrm{N}$, in which amino acids 71-100 were deleted from the amino-terminal end of the receptor (28). The epitopes for the anti-TR $\beta$ - 1 antibody are contained within this deleted region since the synthetic peptide used to generate the antibody was derived from amino acids 73-93. Therefore, when $\Delta \mathrm{N}$ was mixed with either Mf-1 or TR $\beta$-1, we expected the antibody to supershift Mf- 1 and TR $\beta-1$ homodimers as well as receptor $\Delta \mathrm{N}$ dimers, but not $\Delta \mathrm{N}$ homodimers, thereby confirming the formation of any receptor/ $\Delta \mathrm{N}$ dimers. $\Delta \mathrm{N}$ bound weakly as a homodimer with similar mobility as TR $\beta$-1 and dissociated from F2 after the addition of $10^{-7} \mathrm{M} \mathrm{T}_{3}$. (Fig. $6 A$, lanes 4 and 5 ). When it was mixed with $\operatorname{TR} \beta-1$, an intense band was observed in the region of the homodimer (Fig. $6 A$, lane 6 ), which likely represented TR $\beta$-1 homodimers and new $\operatorname{TR} \beta-1 / \Delta \mathrm{N}$ dimers as these complexes were supershifted with anti-TR $\beta$ - 1 antibody (Fig. $6 C$, lanes 1 and 2). Similar results were seen when $\Delta \mathrm{N}$ was mixed with Mf-1 (Fig. $6 B$ and $C$ ). When $10^{-7} \mathrm{M} \mathrm{T}_{3}$ was added to the DNA-binding reactions containing $T R \beta-1$ and $\Delta N$, all the dimer binding was abolished as expected since both TR $\beta-1$ and $\Delta \mathrm{N}$ homodimers dissociated from $\mathrm{F} 2$ at this $\mathrm{T}_{3}$ concentration (Fig. $6 A$, lane 7). However, similar to the case of TR $\alpha-1 /$ Mf-1 dimers, $10^{-7} \mathrm{M} \mathrm{T}_{3}$ decreased most of the intensity of the large band representing mainly Mf- $1 / \Delta \mathrm{N}$ dimers (Fig. $6 \mathrm{~B}$, lanes 7 and 10). The small amount of residual bound complexes observed at this $T_{3}$ concentration dissociated from $F 2$ at $10^{-5} \mathrm{M}$ 

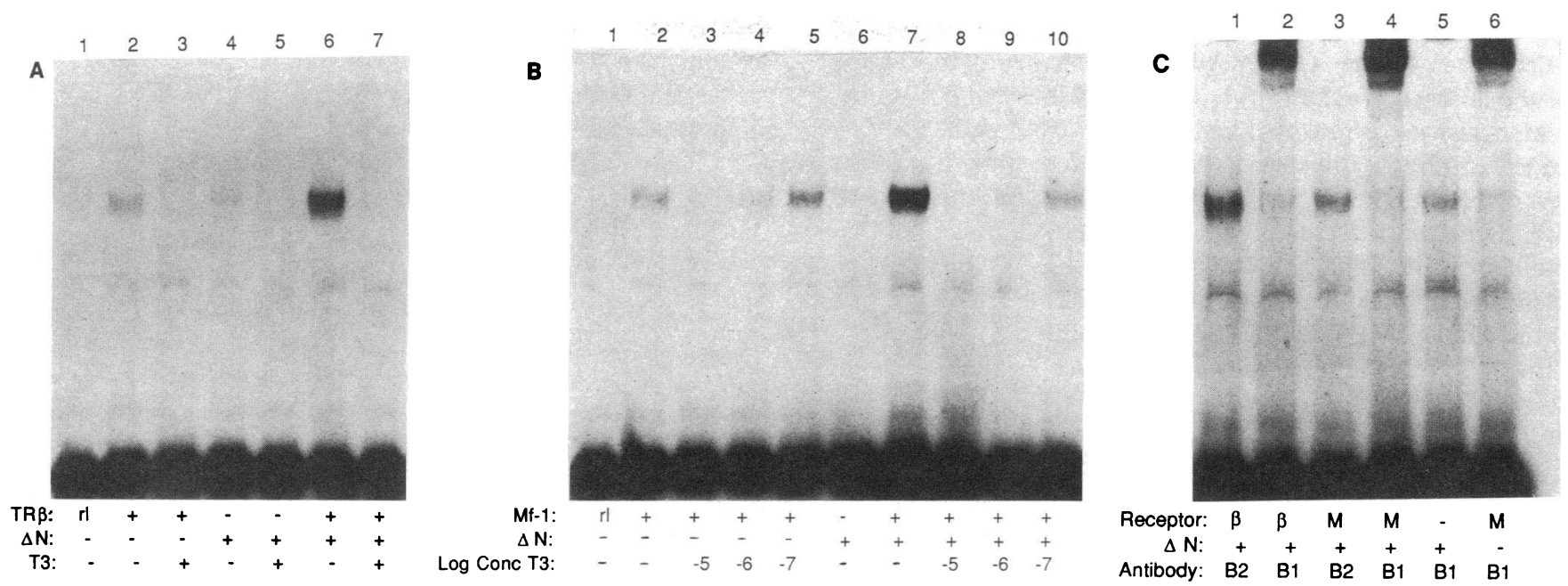

Figure 6. Formation of TR $\beta-1$ and Mf-1 dimers with $\Delta \mathrm{N}$ on F2 and the effect of T3. TR $\beta-1$ or Mf-1 $(0.5 \mu \mathrm{l})$ was incubated with $\Delta \mathrm{N}(6 \mu \mathrm{l})$ in the absence and presence of different concentrations of T3 and was analyzed by EMSA. As in Fig. 5, 1.75-fold more TR $\beta-1$ than MF-1 was added to the DNA-binding reactions. Some samples were incubated with 1:120 diluted rabbit polyclonal antiserum specific for TR isoforms to confirm the formation of dimers. $(A) \mathrm{TR} \beta, \Delta \mathrm{N}$, and TR $\beta / \Delta \mathrm{N}$ dimer binding to $\mathrm{F} 2$ in the absence and presence of $10^{-7} \mathrm{M} \mathrm{T3}$. $(B) \mathrm{Mf}-1$ and $\mathrm{Mf}-1 / \Delta \mathrm{N}$ binding to $\mathrm{F} 2$ in the absence and presence of the indicated concentrations of T3. ( $C$ ) Antibody supershift of TR $\beta-1$ and $\mathrm{Mf}-1$ dimers with $\Delta \mathrm{N}$. The presence $(+)$ or absence $(-)$ of additives is indicated. $\mathrm{rl}$, reticulocyte lysate; $\Delta \mathrm{N}$, wild-type TR $\beta-1$ lacking amino acids $71-100$, located on the amino terminus of the DNA binding domain. $\beta$, TR $\beta-1 ; \mathrm{M}, \mathrm{Mf}-1 ; \mathrm{B} 1$, antiserum against the amino terminus of TR $\beta-1$ (amino acids 73-93). $B 2$, antiserum against the amino terminus of $\operatorname{TR} \beta-2$, which is different than $\operatorname{TR} \beta-1$, used here as control.

$\mathrm{T}_{3}$ and presumably represented a small amount of DNAbound Mf-1 homodimers. These results suggest that for Mf-1 / $\Delta \mathrm{N}$ dimer only $\Delta \mathrm{N}$ needs to bind $\mathrm{T}_{3}$ for this complex to dissociate from DNA.

Lastly, we mixed equal concentrations of both $\operatorname{TR} \beta-1$ and $\mathrm{Mf}-1$ and determined the amount of receptor bound to F2 in the presence or absence of $\mathrm{T}_{3}$. If $\mathrm{Mf}-1$ homodimerized and dimerized equally well with TR $\beta$-1, the mixture would be composed of $\sim 25 \%$ Mf- 1 homodimers, $50 \%$ Mf- 1 / TR $\beta$ - 1 dimers, and $25 \%$ TR $\beta-1$ homodimers. Furthermore, if Mf- $1 /$ TR $\beta-1$ dimer had decreased sensitivity to the $T_{3}$-mediated dissociation from DNA as did Mf- 1 homodimer, $\sim 75 \%$ of the receptor mixture would remain bound at $10^{-7} \mathrm{M} \mathrm{T}_{3}$. In contrast, we observed only $33 \%$ of the receptor dimer mixture remained bound to F2 at $10^{-7} \mathrm{M} \mathrm{T}_{3}$ (Fig. 7), suggesting that Mf-1 / TR $\beta$ 1 dimers dissociated from $F 2$. The remaining bound complexes likely represented Mf-1 homodimers for two reasons: Mf- 1 homodimers remain bound to $\mathrm{F} 2$ at this $\mathrm{T}_{3}$ concentration, and there are more $\mathrm{Mf}-1$ than $\mathrm{TR} \beta-1$ homodimers for the same amount of total receptor (Fig. 2) so they would be expected to represent $>25 \%$ of the total receptors. Similar to the studies of Mf- 1 dimerization with $\mathrm{TR} \alpha-1$ and $\Delta \mathrm{N}$, these results suggest that only one TR (in this case TR $\beta-1$ ) needs to bind $\mathrm{T}_{3}$ for the Mf-1 / TR dimer to dissociate from DNA.

\section{Discussion}

To understand the potential mechanisms by which mutant TR $\beta$-1's exert their dominant negative effect on normal TR function in patients with GRTH, we studied the in vitro DNAbinding of $\mathrm{Mf}-1$, which contains a single amino acid substitution (Gly345 to Arg) in the ligand-binding domain. In particular, we compared TR $\beta-1$ and Mf- 1 homodimerization, receptor isoform dimerization, and receptor heterodimerization with TRAP and RXR $\beta$, using EMSA. Since it previously had been reported that $\mathrm{Mf}-1$ had minimal $\mathrm{T}_{3}$ binding, we also examined the effect of $\mathrm{T}_{3}$ on these receptor complexes.
We found that Mf-1 bound primarily as a homodimer to specific TREs, in a similar manner as TR $\beta-1$. The mobility of both the monomer and dimer bands of Mf-1 were slower on EMSA than for $\operatorname{TR} \beta-1$. This change in mobility was probably due to the additional positive charge of the receptor produced by the glycine to arginine substitution. The Mf- 1 homodimer bound better than TR $\beta-1$ to two different TREs at the same receptor concentration. Scatchard analyses of receptor homodimer binding to $\mathrm{F} 2$ showed that both receptors had similar $K_{\mathrm{d}} \mathrm{s}$, but more Mf-1 homodimer bound to the TRE than an equal amount of translated TR $\beta-1$. This suggests that Mf -1 has a larger pool of homodimers capable of binding F2 than TR $\beta$ -

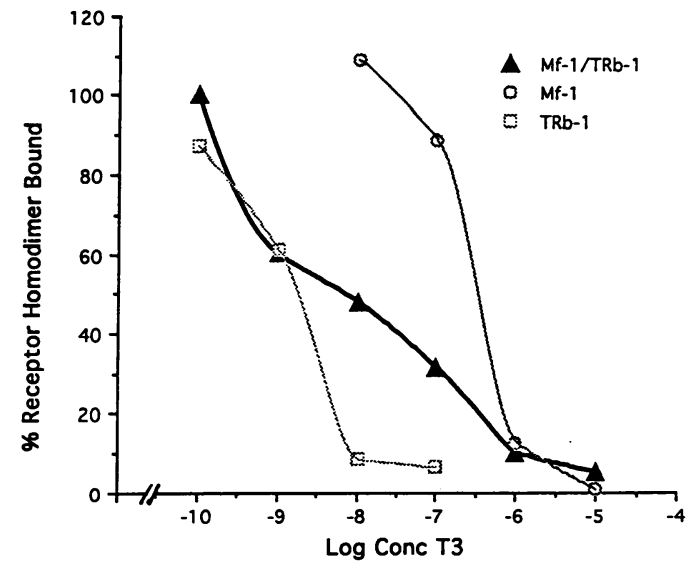

Figure 7. T3 effect on TR $\beta-1$, Mf-1, and Mf-1/TR $\beta$-1 dimer binding to F2 TRE. Equal amounts of TR $\beta-1$ and Mf- 1 receptor were incubated alone or together in the absence or presence of different concentrations of T3 and were analyzed by EMSA. The densities of dimer bands on the fluorographs were quantitated with a laser densitometer (Molecular Dynamics, Sunnyvale, CA). The density of dimer band bound in the absence of T3 was set as maximal dimer bound (100\%). All other bands were normalized as percent dimer bound. 
1, perhaps because of greater homodimer stability. Recently it has been shown that TR/TRAP heterodimers form in solution in the absence of DNA (24), so it is possible that TR homodimers also are formed before binding to DNA. When $T_{3}$ was added to receptor in the DNA-binding reactions, it induced loss of TR $\beta$ - 1 homodimer binding to F2 $\left(\mathrm{EC}_{50}\right.$ of $\sim 1.0 \times 10^{-9}$ $M)$, as we had reported previously (25). In contrast, Mf-1 remained bound to $\mathrm{F} 2$ as a homodimer at $10^{-7} \mathrm{M} \mathrm{T}_{3}$ and completely dissociated from the TRE only at $10^{-5} \mathrm{M} \mathrm{T}_{3}$. These results argue that $\mathrm{Mf}-1$ homodimer may be the major homodimer species bound to TREs in vivo given its greater binding to two TREs of distinctly different orientations (F2 [inverted palindrome] and DR4 [direct repeat]) as well as its markedly diminished ability to dissociate from DNA in the presence of $\mathrm{T}_{3}$.

We next examined the ability of $\mathrm{Mf}-1$ to heterodimerize with TRAP on two different TREs, F2 and DR4. We found that, as in the case of TR $\beta-1$, Mf- 1 heterodimerized with TRAP on both TREs. The mobility of the Mf-1 / TRAP band also was slower than the TR $\beta$-1 / TRAP band. However, when the Mf-1 heterodimer and homodimer binding pattern on these TREs was compared with TR $\beta-1$, Mf- 1 formed homodimer preferentially to heterodimer, whereas $\operatorname{TR} \beta-1$ had an opposite tendency. This difference in the dimer binding pattern of the two receptors may be due to the ability of $\mathrm{Mf}-1$ to homodimerize better than TR $\beta$-1 on some TREs. As previously reported (25), addition of $T_{3}$ to $T R \beta-1$ and nuclear extract in DNA-binding reactions abolished homodimer binding to DNA, but not TR $\beta$ 1/TRAP heterodimer binding. In contrast, addition of $T_{3}$ to Mf- 1 and nuclear extract did not affect the amount of heteroor homodimer binding. Recently, it has been shown that $\operatorname{RXR} \beta$ heterodimerizes with TR and enhances TR binding to TREs $(30,31,34)$. Moreover, we found that TR $\beta-1 / \operatorname{RXR} \beta$ heterodimers remained bound to TREs in the presence of $T_{3}$, so RXR $\beta$ may function similarly to TRAP (36a). In our experiments, Mf- 1 heterodimerized with $\operatorname{RXR} \beta$ in a similar manner as $\operatorname{TR} \beta-1$. Also, the receptor/RXR $\beta$ heterodimer band migrated faster than the receptor/TRAP heterodimer band, and thus it is possible murine $\operatorname{RXR} \beta$ is different than TRAP in the rat pituitary $235-1$ cells. Recently the rat $R X R \beta$ was cloned and found to be virtually identical to its mouse homolog, making it unlikely that species differences in $\operatorname{RXR} \beta$ could account for the different migration pattern of the TR/RXR $\beta$ and TR/pituitary TRAP heterodimers (34).

We next examined the ability of Mf- 1 to form dimers with TR $\alpha-1$ and TR $\beta-1$ and the effect of $T_{3}$ on these receptor/receptor dimers. Mf- 1 formed dimers with TR $\alpha-1$ and $\Delta \mathrm{N}$, a mutant rat $T R \beta-1$ that has an internal deletion in the amino terminus. Using isoform-specific antibodies, we confirmed that TR $\beta$-1 and Mf-1 formed dimers with $\operatorname{TR} \alpha-1$ and $\Delta \mathrm{N}$. Interestingly, $10^{-7} \mathrm{M} \mathrm{T}_{3}$ disrupted the DNA-binding of dimers of TR $\beta-1$ and Mf- 1 that were formed with TR $\alpha-1$ or $\Delta \mathrm{N}$. Since Mf-1 homodimer binding to $F 2$ was abolished only at $10^{-5} M T_{3}$, this suggests that only one member of the TR $\alpha-1$ /Mf-1 and Mf-1/ $\Delta \mathrm{N}$ dimers needs to bind $\mathrm{T}_{3}$ in order for the complex to dissociate. Moreover, since $\mathrm{Mf}-1 /$ receptor dimer dissociated at the same concentration as the $\operatorname{TR} \alpha-1 / \operatorname{TR} \beta-1$ and $\operatorname{TR} \beta-1 / \Delta N$ dimers, ligand affects the $\mathrm{Mf}-1 /$ receptor dimers in a similar manner as TR $\beta-1 /$ receptor dimers. A current model for the dominant negative effect by mutant receptors invokes direct interaction of the mutant receptor with normal receptors, creating a pool of inactive mutant receptor/native receptor dimers that cannot respond normally to $T_{3}$. Our data argue that this is not the case since the $\mathrm{Mf}-1$ / receptor dimers behave similarly to $T R \beta-1 /$ receptor dimers in the presence of $T_{3}$.

Several investigators have reported that unliganded TR suppresses basal transcription by positively regulated TREs $(43,44)$. Additionally, other investigators have reported that v-erbA, a viral oncogene homolog of TR, can block $T_{3}$-mediated transactivation by TRs, perhaps by binding to TREs $(45,46)$. We previously have proposed that $T_{3}$-induced dissociation of homodimers from TREs may be necessary to remove repression before ligand-bound heterodimer can regulate transcription (25). If this is the case, it is conceivable that a mutant receptor that binds very poorly to $\mathrm{T}_{3}$, when bound as a homodimer to a TRE, may maintain a target gene in a tonically repressed state. Increased expression or stability of the mutant TR, as well as increased binding to some TREs, may further augment this repressive ability of the mutant TR. Another possible mechanism for a mutant receptor to decrease sensitivity to $T_{3}$ is based on our previous observation that ligand-bound TR/TRAP heterodimer is the only receptor complex that remains bound to several TREs in the presence of $T_{3}(25)$. This, in turn, suggests that the TR/TRAP heterodimer may be the functionally relevant receptor form in $T_{3}$-mediated transcription for some genes (25). Since Mf- 1 binds poorly to $T_{3}$, the Mf-1/TRAP heterodimer would not be expected to mediate ligand-regulated transcription by this mechanism. Thus, formation of mutant TR/nuclear protein heterodimers may have a dominant negative effect either by titrating limiting amounts of auxiliary proteins or coactivators (squelching) or by competing with wild-type TR/nuclear protein heterodimers for binding to TREs. In a given cell, alterations in the expression of Mf-1 or the stability of Mf-1/TRAP heterodimers compared with normal TR/TRAP heterodimers could affect the population of abnormal heterodimers and thereby determine the amount of $\mathrm{T}_{3}$ resistance in the cell.

On the basis of our data, we propose that the dominant negative effect by $\mathrm{Mf}-1$ and the decreased sensitivity to $T_{3}$ within the cells of the patients with this mutation are not due to abnormal interactions with $\operatorname{TR} \alpha-1$ and $T R \beta-1$ by Mf- 1 . Instead, they likely occur by one or both of the following mechanisms: repression by mutant homodimers that bind to TREs but do not dissociate from the TREs in the presence of $T_{3}$ and/or diminished ligand-regulated transcription by $\mathrm{Mf}-1$ / TRAP heterodimers since Mf- 1 binds poorly to $T_{3}$. The possibility of multiple regulatory steps that might affect these two mechanisms and differences in impairment of $T_{3}$ binding among the different $\operatorname{TR} \beta-1$ mutations observed in kindreds with GRTH may account for the variability in tissue resistance to $T_{3}$ in affected patients as well as the differences in phenotypes among kindreds with this syndrome.

\section{Acknowledgments}

The authors thank Dr. Douglas Darling and Dr. Keiko Ozato for their generous gifts of plasmids encoding $\Delta N$ and H-2RIIBP, respectively, and Dr. Thomas Lee (Brigham and Women's Hospital, Boston, MA) for assistance in the statistical analyses of the Scatchard plots.

This work was supported by National Institutes of Health grants DK-15070 and RR-00055.

\section{References}

1. Lamberg, B.-A., and K. Liewendahl. 1980. Thyroid hormone resistance. Ann. Clin. Res. 12:243-253.

2. Refetoff, S. 1990. Resistance to thyroid hormone revisited. Thyroid Today. 13(3):1-11. 
3. Magner, J. A., P. Petrick, M. M. Menezes-Ferreira, M. Stelling, and B. D. Weintraub. 1986. Familial generalized resistance to thyroid hormones: report of three kindreds and correlation of patterns of affected tissues with the binding of [ $\left.{ }^{125} \mathrm{I}\right]$ triiodothyronine to fibroblast nuclei. J. Endocrinol. Invest. 9:459-470.

4. Takeda, K., A. Sakurai, L. J. DeGroot, and S. Refetoff. 1992. Recessive inheritance of thyroid hormone resistance caused by complete deletion of the protein-coding region of the thyroid hormone receptor- $\beta$ gene. J. Clin. Endocrinol. Metab. 74:49-55.

5. Bernal, J., S. Refetoff, and L. J. DeGroot. 1978. Abnormalities of triiodothyronine binding to lymphocyte and fibroblast nuclei from a patient with periphera resistance to thyroid hormone action. J. Clin. Endocrinol. Metab. 47:1266-1272.

6. Weinberger, C., C. C. Thompson, E. S. Ong, R. Lebo, D. J. Gruol, and R. M. Evans. 1986. The $c$-erb-A gene encodes a thyroid hormone receptor. $\mathrm{Na}$ ture (Lond.). 324:641-646.

7. Nakai, A., A. Sakurai, G. I. Bell, and L. J. DeGroot. 1988. Characterization of a third human thyroid hormone receptor coexpressed with other thyroid hormone receptors in several tissues. Mol. Endocrinol. 2:1087-1092.

8. Miyajima, N., R. Horiuchi, Y. Shibuya, S. Fukushige, K. Matsubara, K. Toyoshima, and T. Yamamoto. 1989. Two erbA homologs encoding proteins with different $\mathrm{T} 3$ binding capacities are transcribed from opposite DNA strands of the same genetic locus. Cell. 57:31-39.

9. Evans, R. M. 1988. The steroid and thyroid hormone receptor superfamily. Science (Wash. DC). 240:889-895.

10. Beato, M. 1989. Gene regulation by steroid hormones. Cell. 56:335-344.

11. Sakurai, A., K. Takeda, K. Ain, P. Ceccarelli, A. Nakai, S. Seino, G. I. Bell, S. Refetoff, and L. J. DeGroot. 1989. Generalized resistance to thyroid hormone associated with a mutation in the ligand-binding domain of the human thyroid hormone receptor $\beta$. Proc. Natl. Acad. Sci. USA. 86:8977-8981.

12. Usala, S. J., G. E. Tennyson, A. E. Bale, R. W. Lash, N. Gesundheit, F. E. Wondisford, D. Accili, P. Hauser, and B. D. Weintraub. 1990. A base mutation of the c-erbA $\beta$ thyroid hormone receptor in a kindred with generalized thyroid hormone resistance. Molecular heterogeneity in two other kindreds. J. Clin. Invest. 85:93-100.

13. Usala, S. J., J. B. Menke, T. L. Watson, J. Bérard, W. E. C. Bradley, A. E. Bale, R. W. Lash, and B. D. Weintraub. 1991. A new point mutation in the 3,5,3'-triiodothyronine-binding domain of the c-erbA $\beta$ thyroid hormone receptor is tightly linked to generalized thyroid hormone resistance. J. Clin. Endocrinol. Metab. 72:32-38.

14. Boothroyd, C. V., B. T. Teh, N. K. Hayward, P. E. Hickman, G. J. Ward, and D. P. Cameron. 1991. Single base mutation in the hormone binding domain of the thyroid hormone receptor $\beta$ gene in generalized thyroid hormone resistance demonstrated by single stranded conformation polymorphism analysis. Biochem. Biophys. Res. Commun. 178:606-612.

15. Parrilla, R., A. J. Mixson, J. A. McPherson, J. H. McClaskey, and B. D. Weintraub. 1991. Characterization of seven novel mutations of the c-erbA $\beta$ gene in unrelated kindreds with generalized thyroid hormone resistance. Evidence for two "hot spot" regions of the ligand binding domain. J. Clin. Invest. 88:21232130 .

16. Takeda, K., R. E. Weiss, and S. Refetoff. 1992. Rapid location of mutations in the thyroid hormone receptor $\beta$ gene by denaturing gradient electrophoresis in eighteen families with thyroid hormone resistance. J. Clin. Endocrinol Metab. 74:712-719.

17. Usala, S. J., F. E. Wondisford, T. L. Watson, J. B. Menke, and B. D. Weintraub. 1990. Thyroid hormone and DNA binding properties of a mutan c-erbA $\beta$ receptor associated with generalized thyroid hormone resistance. Biochem. Biophys. Res. Commun. 171:575-580.

18. Sakurai, A., T. Miyamoto, S. Refetoff, and L. J. DeGroot. 1990. Dominant negative transcriptional regulation by a mutant thyroid hormone receptor $\beta$ in a family with generalized resistance to thyroid hormone. Mol. Endocrinol. 4:1988-1994.

19. Chatterjee, V. K. K., T. Nagaya, L. D. Madison, S. Datta, A. Rentoumis and J. L. Jameson. 1991. Thyroid hormone resistance syndrome. Inhibition of normal receptor function by mutant thyroid hormone receptors. J. Clin. Invest. 87:1977-1984.

20. Forman, B. M., C. R. Yang, M. Au, J. Casanova, J. Ghysdael, and H. H. Samuels. 1989. A domain containing leucine-zipper-like motifs mediate novel in vivo interactions between the thyroid hormone and retinoic acid receptors. $\mathrm{Mol}$. Endocrinol. 3:1610-1626.

21. Lazar, M. A., and T. Berrodin. 1990. Thyroid hormone receptors form distinct nuclear protein-dependent and independent complexes with a thyroid hormone response element. Mol. Endocrinol. 4:1627-1635.

22. Holloway, J. M., C. K. Glass, S. Adler, C. A. Nelson, and M. G. Rosenfeld. 1990. The C'-terminal interaction domain of the thyroid hormone receptor confers the ability of the DNA site to dictate positive or negative transcriptional activity. Proc. Natl. Acad. Sci. USA. 87:8160-8164.

23. Brent, G. A., G. R. Williams, J. W. Harney, B. M. Forman, H. H. Samuels, D. D. Moore, and P. R. Larsen. 1991. Effects of varying the position of thyroid hormone response elements within the rat growth hormone promoter: implications for positive and negative regulation by 3,5,3'-triiodothyronine. $\mathrm{Mol}$. Endocrinol. 5:542-548.
24. Lazar, M. A., T. J. Berrodin, and H. H. Harding. 1991. Differential DNA binding by monomeric, homodimeric, and potentially heteromeric forms of the thyroid hormone receptor. Mol. Cell Biol. 11:5005-5015.

25. Yen, P. M., D. S. Darling, R. L. Carter, M. Forgione, P. K. Umeda, and W. W. Chin. 1992. T3 decreases binding to DNA by T3-receptor homodimers but not receptor-auxiliary protein heterodimers. J. Biol. Chem. 267:3565-3568.

26. Burnside, J., D. S. Darling, and W. W. Chin. 1990. A nuclear factor that enhances binding of thyroid hormone receptors to thyroid hormone response elements. J. Biol. Chem. 265:2500-2504.

27. Murray, M. B., and H. C. Towle. 1989. Identification of nuclear factors that enhance binding of the thyroid hormone receptor to a thyroid hormone response element. Mol. Endocrinol. 3:1434-1442.

28. Darling, D. S., J. S. Beebe, J. Burnside, E. R. Winslow, and W. W. Chin 1991. 3,5,3'-triiodothyronine (T3) receptor-auxiliary protein (TRAP) binds DNA and forms heterodimers with the T3 receptor. Mol. Endocrinol. 5:73-84.

29. Beebe, J. S., D. S. Darling, and W. W. Chin. 1991. 3,5,3'-triiodothyronine receptor auxiliary protein (TRAP) enhances receptor binding by interactions within the thyroid hormone response element. Mol. Endocrinol. 5:85-93.

30. Hamada, K., S. L. Gleason, B. Z. Levi, S. Hirschfelld, E. Apella, and K Ozato. 1989. H-2RIIBP, a member of the nuclear hormone receptor superfamily that binds to both the regulatory element of major histocompatibility class I genes and the estrogen response element. Proc. Natl. Acad. Sci. USA. 86:8289-8293.

31. Yu, V. C., C. Delsert, B. Andersen, J. M. Holloway, O. V. Devary, A. M. Naar, S. Y. Kim, J. M. Boutin, C. K. Glass, and M. G. Rosenfeld. 1991. RXRB: a coregulator that enhances binding of retinoic acid, thyroid hormone, and vitamin D receptors to their cognate response elements. Cell. 67:1251-1266.

32. Kliewer, S. A., K. Umesono, D. Mangelsdorf, and R. M. Evans. 1992. Retinoid $\mathrm{X}$ receptor interacts with nuclear receptors in retinoic acid, thyroid hormone, and vitamin D3 signalling. Nature (Lond.). 355:446-449.

33. Marks, M. S., P. M. Hallenbeck, T. Nagata, J. H. Segars, E. Appella, V. M Nikodem, and K. Ozato. 1992. H-2RIIBP (RXR $\beta$ ) heterodimerization provides a mechanism for combinatorial diversity in the regulation of retinoic acid and thyroid hormone responsive genes. EMBO (Eur. Mol. Biol. Organ.) J. 11:14191435.

34. Zhang, X. K., B. Hoffman, P. B.-V. Tran, G. Graupner, and M. Pfahl. 1992. Retinoid $X$ receptor is an auxiliary protein for thyroid hormone and retinoic acid receptors. Nature (Lond.). 355:441-446.

35. Leid, M., P. Kastner, R. Lyons, H. Naksatri, M. Saunders, T. Zacharewski, J. Y. Chen, A. Staub, J.-M. Garnier, S. Mader, et al. 1992. Purification, cloning, RXR identity of the HeLa cell factor with which RAR or TR heterodimerizes to bind target sequences efficiently. Cell. 68:377-395.

36. Heyman, R. A., D. J. Mangelsdorf, J. A. Dyk, R. B. Stein, G. Eichele, R. M. Evans, and C. Thalle. 1992. 9-cis retinoic acid is a high affinity ligand for the retinoid X receptor. Cell. 68:397-406.

36a.Yen, P. M., A. Sugawara, and W. W. Chin. 1992. Triiodothyronine ( $\left.T_{3}\right)$ differentially affects $T_{3}$-receptor/retinoic acid receptor and $T_{3}$-receptor/retinoid $X$ receptor heterodimer binding to DNA. J. Biol. Chem. In press.

37. Thompson, C. C., C. Weinberger, R. Lebo, and R. M. Evans. 1987. Identification of a novel thyroid hormone receptor expressed in the mammalian central nervous system. Science (Wash. DC). 237:1610-1614.

38. Lazar, M. A., R. A. Hodin, and W. W. Chin. 1989. Human carboxyl-terminal variant of $\alpha$-type c-erbA inhibits trans-activation by thyroid hormone receptors without binding thyroid hormone. Proc. Natl. Acad. Sci. USA. 86:77717774.

39. Burnside, J., D. S. Darling, F. Carr, and W. W. Chin. 1989. Thyroid hormone regulation of the rat glycoprotein $\alpha$-subunit gene promoter activity. $J$. Biol. Chem. 264:6886-6897.

40. Baniahmad, A., C. Steiner, A. C. Kohne, and R. Renkawitz. 1990. Modular structure of a chicken lysozyme silencer: involvement of an unusual thyroid hormone receptor binding site. Cell. 61:505-514.

41. Umesono, K., K. K. Marakami, C. C. Thompson, and R. M. Evans. 1991. Direct repeats as selective response elements for the thyroid hormone, retinoic acid, and vitamin D3 receptors. Cell. 65:1255-1266.

42. Yen, P. M., M. E. Sunday, D. S. Darling, and W. W. Chin. 1992. Isoformspecific thyroid hormone receptor antibodies detect multiple thyroid hormone receptors in rat and human pituitaries. Endocrinology. 130:1539-1546.

43. Brent, G. A., M. K. Dunn, J. W. Harney, T. Gulick, P. R. Larsen, and D. D. Moore. 1989. Thyroid hormone aporeceptor represses T3-inducible promoters and blocks activity of the retinoic acid receptor. New Biologist. 1:329336.

44. Zhang, X. K., K. N. Wills, G. Graupner, M. Tzukerman, T. Hermann, and M. Pfahl. 1991. Ligand-binding domain of thyroid hormone receptors modulates DNA binding and determines their bifunctional roles. New Biologist. 3:169181.

45. Sap, J., A. Munoz, J. Schmitt, H. Stunnenberg, and B. Vennstrom. 1989. Repression of transcription mediated at thyroid hormone response element by the v-erbA oncogene product. Nature (Lond.). 340:242-244.

46. Damm, K., C. C. Thompson, and R. M. Evans. 1989. Protein encoded by $\mathrm{v}$-erbA functions as a thyroid-hormone receptor antagonist. Nature (Lond.). 339:593-597. 